Acta vet. scand. 1961, 2, 226-235.

From the Departments of Medicin for Non-Ruminants and of Clinical Biochemistry at the Royal Veterinary College, Stockholm.

\title{
PRODUCTION OF MUSCULAR DYSTROPHY IN PIGS BY FEEDING CO'TTONSEED OIL
}

\author{
By \\ Paul Lindberg and Kerstin Orstadius.
}

Muscular dystrophy (MD) is widespread in Sweden. The incidence varies considerably from one year to another. The disease has been produced experimentally by feeding grain (mixed oats, barley and wheat) which was associated with field outbreaks $(9,20,20 \mathrm{a})$. It can therefore be supposed that some years the grain, which is the main ingredient of swine food, may have a composition that is responsible for the outbreaks of MD.

According to observations by some research workers (19) grains responsible for MD in pigs would be characterized by high peroxide values.

It has also been observed that MD can be produced by feeding cod-liver oil $(6,10)$, whereas diets containing lard as the source of fat have given somewhat contradictory results. In our own experiments a vitamin-E-deficient basic diet with addition of stripped lard, 5 per cent, did not induce MD (10).

These observations indicate that the fat of the grain may be of essential importance.

In searching for a readily available vegetable oil with a fatty acid composition similar to the fat of grain, we found that cottonseed oil (CSO) fulfilled these requirements. This oil was therefore used in the feeding experiments described here.

\section{MATERIAL AND METHODS}

The pigs used belonged to the Swedish Land Breed or the English Large White Breed or were crosses between these two. They were collected from farms known to be free from contagious 
diseases, such as enzootic virus pneumonia and atrophic rhinitis, and where the health of the animals is regularly checked by a veterinarian. At the beginning of the experiment they weighed $20-25 \mathrm{~kg}$. Both females and castrated males were represented. Each group consisted of five pigs. In grouping the pigs litter-mates were, as far as possible, equally distributed among the different groups.

The basic diet (BD) had the following composition:

Casein 15 per cent, Dried Brewer's Yeast 20 per cent, Sucrose 50-59.5 per cent (amounts varying depending on amounts of fat), Commercial mineral mixture 5 per cent.

The mineral mixture contained approximately 75 per cent dicalcium phosphate, 25 per cent disodium phosphate, supplements of iron, copper and cobalt as sulphates, and iodide.

The ingredients of the BD were delivered by the same manufacturers throughout the experiments. For experiments II and III BD was composed of one and the same delivery.

At the beginning of each experiment the pigs were given 100,000 I.U. of vitamin $A$ and 250,000 I.U. of vitamin $D_{2}$ by intramuscular injections.

Varying amounts of CSO were thoroughly mixed with the BD in a food mixer immediately before feeding. The food was then given as a dry mash. The pigs had free access to water.

Heating of the $\mathrm{CSO}$ was done at $100^{\circ} \mathrm{C}$ under continuous flow of air. In some experiments the CSO was stripped of most of its tocopherols by molecular distillation. The oils were stored in tight containers in a cool place.

Tocopherols, peroxide value (PV), glutamic-oxaloacetic transaminase (GOT) and ornithine carbamyl transferase (OCT) were determined as described in previous papers $(10,22)$.

The relation between plasma-GOT values and the morphological status of the muscles with regard to MD was studied in earlier papers $(9,10,15)$.

For some determinations of tocopherols paper chromatography (18) was used.

Polyunsaturated fatty acids (PFA) were estimated by the following modification of McGee's (13) method: 300-500 mg. of fat are dissolved in $25 \mathrm{ml}$. of benzene-methanol mixture $(30: 70$ by volume). $1 \mathrm{ml}$. of the solution is taken into a test tube and the solvent is evaporated at reduced pressure in a $40^{\circ} \mathrm{C}$ water bath and $10 \mathrm{ml} .0 .5 \mathrm{~N}$ alcoholic potassium hydroxide are added. The 
mixture is kept in the dark overnight. $1 \mathrm{ml}$. is pipetted into a 100 ml. volumetric flask. $20 \mathrm{ml}$. of $1 \mathrm{M}$ potassium-borate buffer ( $\mathrm{pH}$ 9.0 ), $1 \mathrm{ml}$. of $0.5 \mathrm{~N}$ hydrochloric acid and distilled water to 100 ml. are added.

Gas-liquid chromatography (GLC) was carried out with a Perkin-Elmer Fractometer 116E, using 2 metres standard column and having as stationary phase succinate polyester of diethylene glycol, 20 per cent by weight on $60-80$ mesh chromosorb.

The column was operated at $210^{\circ} \mathrm{C}$ with helium as the carrier gas flowing at $100 \mathrm{ml}$. per minute. A hot wire detector was used.

Methyl esters of fatty acids were prepared as follows.

Ten g. of grain or BD are homogenized with $25 \mathrm{ml}$. of benzenemehanol mixture which is poured into a column with a small wad of cotton wool in the bottom. Solvent is allowed to extract through the column at a rate of about 1 drop every second until $200 \mathrm{ml}$. are collected in the volumetric receiving flask.

Solvent is removed under reduced pressure. Lipids are seponified with $20 \mathrm{ml}$. of 4 per cent w/v solution of potassium hydroxide in ethanol. After adding of $10 \mathrm{ml}$. of water the non-saponifiable material is extracted three times with $20 \mathrm{ml}$. of petroleum ether. The aqueous phase is acidified with $20 \mathrm{ml}$. of $5 \mathrm{~N}$ sulfuric acid and the fatty acids are extracted three times with an equal volume of petroleum ether. The solvent is distilled off under reduced pressure and water residues are removed by addition of benzene and following evaporation.

After addition of $20 \mathrm{ml}$. of dry methanol and $0.5 \mathrm{ml}$. of sulfuric acid the mixture is left to stand for 24 hours. Ten ml. of water are added and methyl esters are extracted three times with $20 \mathrm{ml}$. of petroleum ether. The extract is washed three times with $10 \mathrm{ml}$. of water and dried with anhydrous sodium sulphate. Solvent is removed by evaporation under reduced pressure.

\section{RESULTS}

Data for the different diets are brought together in Table 1. Results of the GLC analyses of fats will be seen in Table 2.

Plasma-GOT values of the experimental pigs are shown in Diagram 1.

Plasma-OCT determinations were done in all pigs at the start of the experiments and otherwise whenever GOT was elevated. No significant rises were observed. 
Locomotive disturbances, trembling and paralysis were strikingly noticeable in pigs with high plasma-GOT values in experiment II. They were also present though much less markedly in pigs with GOT elevations in experiment III. No such symptoms appeared in experiment $I$.

\section{DISCUSSION}

Cottonseed oil is rich in polyunsaturated fatty acids. Thus, linoleic acid comprises about half of the total fatty acids. A small quantity of linolenic acid is present (Table 2).

The intake of linoleic acid appears to be a primary factor in the aetiology of encephalomalacia and exudative diathesis, being conditions that belong to the vitamin-E-deficiency syndrome in the chick (5). It has been demonstrated that, although encephalomalacia is produced when the linoleic acid content of the diet is above a certain minimum (2), dietary combinations with other fatty acids may enhance or reduce the effect of linoleic acid (3).

Observations that MD in pigs can be induced by the addition of cod-liver oil $(6,10)$ and corn oil $(20,20 \mathrm{a})$ to the diet support the assumption that PFA are of essential importance in the aetiology of the experimental disease. Cod-liver oil is poor in linoleic acid but contains tetraenoic (arachidonic) acid. Since dietary linoleic acid is partly converted into arachidonic acid in animals (14), it is possible that it induces MD in the latter form.

It will be seen from Table 1 and Diagram 1 that MD was produced by addition of 10,3 and 0.5 per cent of stripped CSO to the diet. The molecular distillation, which removed about 90 per cent of the tocopherols, did not materially change the fattyacid pattern of the original oil (Table 2). This apparently means that the balance between the tocopherol-stressing fatty acids and the tocopherols was decisively changed in favour of the former.

As would be expected, experiment III shows a decreasing incidence and intensity of MD as the dietary levels of CSO decrease.

The group receiving 5 per cent lard (group 4, experiment III) did not react with MD. This is in accordance with earlier observations (10). This diet contained approximately the same quantities of PFA and tocopherols as the diet supplemented with 0.5 per cent stripped CSO (group 3, experiment III), where one animal 
T a ble 1. Diets used and data characterizing the fat supplements.

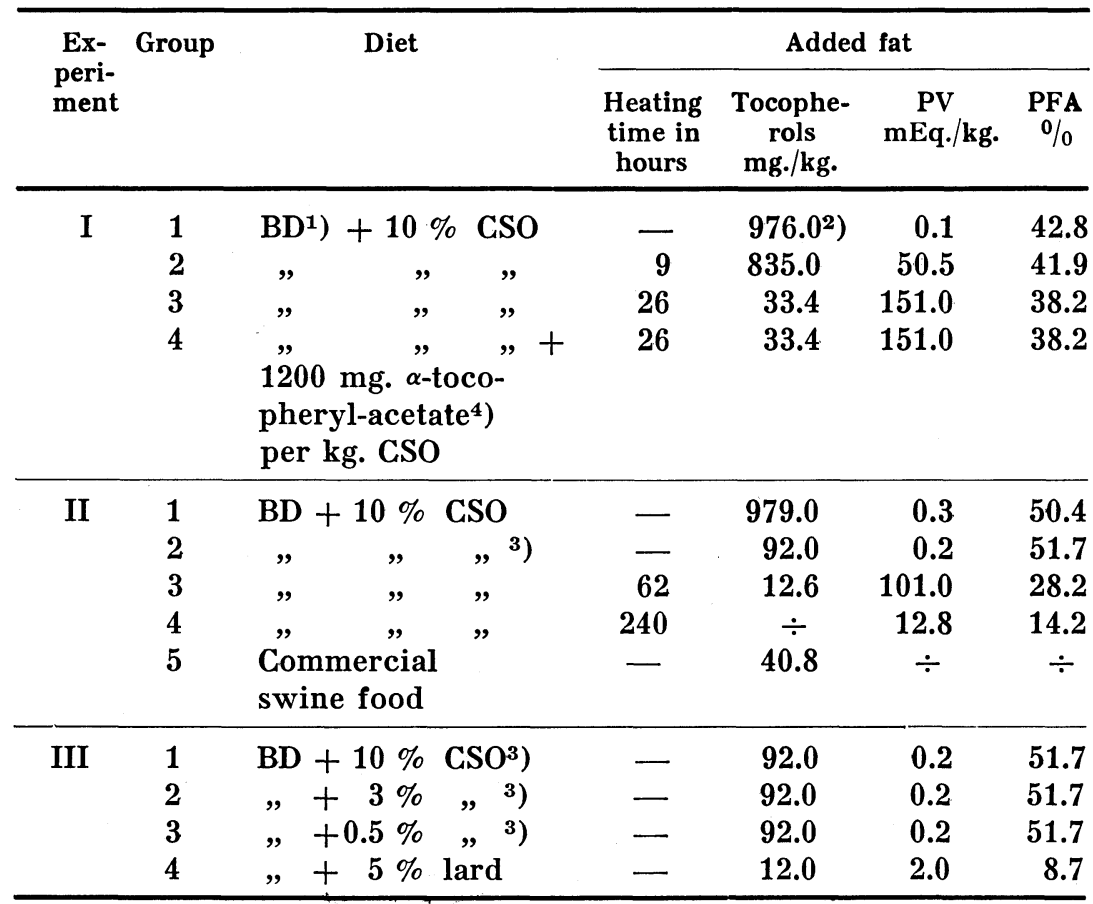

1) Contained $0.28 \%$.crude fat.

2) Value obtained by paper chromatography (56.2\% $\alpha$ - and $43.8 \%$ $\gamma$-tocopherol). Other tocopherol values were obtained without paper chromatography.

3) Stripped of tocopherols.

4) According to the manufacturer's analysis.

T a b l e 2. Relative proportions of fatty acids as determined by GLC in BD and in fats used in experiments II and III.

\begin{tabular}{lccccr}
\hline Fatty acids & Fat of BD & $\begin{array}{c}\text { CSO } \\
\text { unheated }{ }^{1} \text { ) }\end{array}$ & $\begin{array}{c}\text { CSO } \\
\text { stripped } 1\end{array}$ & $\begin{array}{c}\text { CSO heated } \\
\text { 240 hours }{ }^{2}\end{array}$ & Lard \\
\hline Myristic & 8.6 & 1.1 & 0.8 & 1.4 & 2.2 \\
Palmitic & 39.3 & 26.1 & 25.2 & 36.6 & 28.8 \\
Palmitoleic & 18.8 & 0.6 & 0.6 & 0.6 & 2.2 \\
Stearic & 12.3 & 2.5 & 2.9 & 3.7 & 18.4 \\
Oleic & 17.9 & 17.7 & 17.8 & 20.6 & 41.6 \\
Linoleic & 3.1 & 50.6 & 51.5 & 35.4 & 6.6 \\
Linolenic & 0 & 1.5 & 1.3 & 1.6 & 0.9 \\
\hline
\end{tabular}

1) $0.91 \mathrm{~g}$. of methyl esters obtained from $1.00 \mathrm{~g}$. of oil.

2) $0.71 \mathrm{~g}$. of methyl esters obtained from $1.00 \mathrm{~g}$. of oil. 


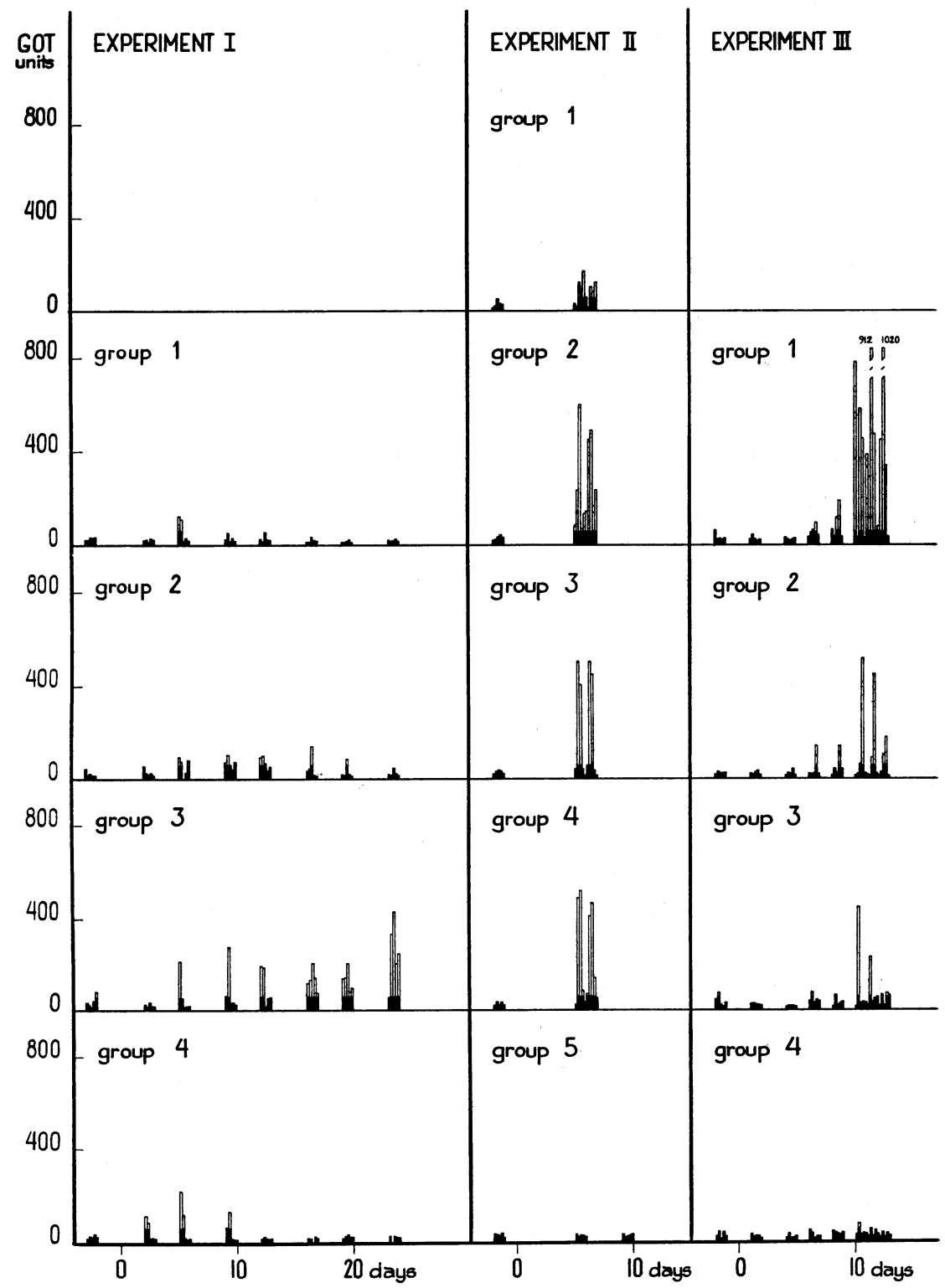

D i a g a m 1. Plasma-GOT values in experiments I-III. Normal area (mean $+2 \times$ standard deviation) is drawn black. The individual values of the pigs are always given in the same order. 
reacted. The different activity thus demonstrated between CSO and lard may possibly be explained by quantitative differences in the fatty-acid pattern of the two fats (Table 2). Lard is richer in oleic acid than is CSO. It is of interest to note that this acid diminished the encephalomalacia-producing capacity of corn oil (3). CSO that had been heated for 26 hours or more was about as effective as stripped oil in producing MD. This can no doubt be explained by low tocopherol values. Heating for only 9 hours with a fairly unaffected tocopherol level, did not significantly increase the MD-producing capacity (group 2, experiment I). Heating for 26 hours or more also destroyed part of the linoleic acid.

The enzymatic method of determining PFA gives values which compare well with those obtained by GLC as far as unheated CSO and lard are concerned (Tables 1 and 2). CSO heated for 240 hours would contain only 14.2 per cent as measured enzymatically, but 37.0 per cent as measured by GLC. The difference in weight of methyl esters as referred to $1 \mathrm{~g}$. of CSO shows that the heating destroyed roughly 22 per cent of the total fatty acids, mainly by oxidation and polymerization of the PFA. This is in good agreement with the percentage of 37.0 for linoleic and linolenic acids obtained by GLC. In contrast to GLC the lipoxidase method does not measure transisomers of PFA. It is possible that isomerization during heating occurred to an amount which accounts for the difference.

PV for the potent oils varies greatly, or between 0.2 and 151.0 $\mathrm{mEq}$ per kg. Peroxides, therefore, do not seem to have any essential influence upon the MD-provoking capacity of fats. This conforms with observations on exsudative diathesis (4), exsudative diathesis and MD (12) in chicks. Toxicity experiments with lipid peroxides given orally to rats resulted not in a disease pattern similar to the vitamin-E deficiency syndrome but in digestive disturbances with diarrhoea and depressed growth $(1,8)$. Possibly, they are not absorbed or are inactivated in the intestine (7).

Slight plasma-GOT elevations may occur sporadically even when the tocopherol content of the diet is high, as, e.g., in group 4, experiment I. This is possibly referable to temporary depression of tocopherol absorption from the intestine. Pigs receiving the experimental diet are inclined to develop temporary diarrhoea during the first few days. The occurrence of ceroid pigment in tissues of human beings who had had chronic gastrointestinal 
disturbances were similarly explained by depressed absorption of tocopherols $(16,21)$.

In a group of pigs fed a dystrophogenic diet a few animals may be resistant, although the majority react. According to our experience, pigs of the same litter react more in the same way than do pigs of different litters. This may be explained by different levels of tissue tocopherols at the start of the experiment or by different "constitution". Accordingly, Schwarz (17) observed differences in the liability to dietetic liver necrosis between different strains of rats.

Grain used for pig feeding is generally composed of barley and oats. The following relative proportions of fatty acids, determined by GLC, were obtained for representative grains harvested in the middle part of Sweden in 1960 (11).

Fatty acids

\begin{tabular}{|c|c|c|c|c|c|c|c|c|c|}
\hline & $\begin{array}{l}\text { My- } \\
\text { ris- } \\
\text { tic }\end{array}$ & $\begin{array}{l}\text { Pal- } \\
\text { mi- } \\
\text { tic }\end{array}$ & $\begin{array}{l}\text { Pal- } \\
\text { mit- } \\
\text { oleic }\end{array}$ & $\begin{array}{l}\text { Stea- } \\
\text { ric }\end{array}$ & Oleic & $\begin{array}{l}\text { Lino- } \\
\text { leic }\end{array}$ & $\begin{array}{l}\text { Lino- } \\
\text { lenic }\end{array}$ & $\begin{array}{l}\text { PFA }^{1)} \\
\text { per } \\
\text { cent }\end{array}$ & $\begin{array}{l}\text { Total }{ }^{2} \text { ) } \\
\text { fatty } \\
\text { acids } \\
\text { per cent }\end{array}$ \\
\hline \multicolumn{10}{|l|}{ Barley U 37} \\
\hline unripe $25 / 7$ & 0.9 & 24.0 & 0.3 & 1.3 & 13.4 & 49.4 & 10.9 & 1.73 & 2.9 \\
\hline$\# \quad 1 / 9$ & 1.1 & 21.8 & 0.8 & 1.9 & 16.6 & 50.7 & 7.1 & 1.15 & 2.0 \\
\hline ripe $\quad 23 / 9$ & 0.9 & 22.8 & 0.4 & 1.3 & 13.0 & 53.6 & 7.9 & 1.39 & 2.3 \\
\hline \multicolumn{10}{|l|}{ Oats U 36} \\
\hline unripe $25 / 7$ & 0.6 & 16.7 & 0.2 & 1.0 & 41.7 & 30.1 & 9.8 & 1.22 & 3.1 \\
\hline,$\quad 1 / 9$ & 0.4 & 13.4 & 0.4 & 1.2 & 28.3 & 51.5 & 4.9 & 1.69 & 3.0 \\
\hline $22 / 9$ & 0.5 & 17.2 & 0.3 & 1.6 & 37.0 & 41.7 & 1.7 & 1.90 & 4.4 \\
\hline
\end{tabular}

1) Enzymatic determination. Figures refer to dry substance.

2) Calculated from PFA value and relative proportions of fatty acids.

It is obvious that the same fatty acids are found as in CSO and that the relative proportions, although changing during different phases of vegetation, are similar. Regarding the quantity of fat, the grains compare well with group 2 in experiment III, which was given CSO, 3 per cent of the diet. Thus there is grounds for the assumption that the fat of barley and oats may well have the capacity of inducing MD. The tocopherol and selenium compounds of the grains vis à vis the PFA content of the latter should be expected to play a key rôle.

Research along this line is in progress and will be published. 


\section{REFERENCES}

1. Andrews, J. S., Mead, J. F. and Griffith, W. H.: Fed. Proc. 1956, $15,918$.

2. Century, B., Horwitt, M. K. and Bailey, P.: A. M. A. Arch. gen. Psychiat. 1959, 1, 420.

3. Century, B. and Horwitt, M. K.: Proc. Soc. exp. Biol. Med. 1959, $102,375$.

4. Dam, H.: Proc. Soc. exp. Biol. Med. 1943, 52, 285.

5. Dam, H., Kofoed Nielsen, G., Prange, I. and Sфndergaard, E.: Nature 1958, 182, 802.

6. Forbes, R. M. and Draper, H. H.: J. Nutr. 1958, 65, 535.

7. Holman, R. T. and Greenberg, S. I.: J. Amer. Oil. Chemists Soc. 1958, 35, 707.

8. Kaunitz, H., Slanetz, C. A., Johnson, R. E., Knight, H. B., Koos, R. E. and Swern, O.: J. Amer. Oil. Chemists Soc. 1959, 36, 611.

9. Lannek, N., Lindberg, P., Nilsson, G., Nordström, G., Orstadius, $K$. and Åberg, B.: Zbl. Vet. Med. 1960, 7, 403.

10. Lannek, N., Lindberg, P., Nilsson, G., Nordström, G. and Orstadius, $K$.: Res. vet. Sci. 1961, 2, 67.

11. Lannek, $N$. and Lindberg, P.: to be published.

12. Machlin, L. J., Gordon, R. S. and Meisky, K. H.: J. Nutr. 1959, 67, 333.

13. McGee, J.: Anal. Chem. 1959, 31, 298.

14. Olson, R. E.: Annu. Rev. Biochem. 1959, 28, 467.

15. Orstadius, K., Wretlind, B., Lindberg, P., Nordström, G. and Lannek, N.: Zbl. Vet.Med. 1959, 6, 971.

16. Pappenheimer, A. M. and Victor, J.: Amer. J. Path. 1946, 22, 395.

17. Schwarz, K.: Liver Function. Ed.: Brauner R. W., p. 509. American Institute of Biological Sciences, Washington 1958.

18. Society for Analytical Chemistry, Analytical Methods Committee. Report prepared by the Vitamin-E Panel. Analyst 1959, 84, 356.

19. Swahn, O. and Rutqvist, L.: Proc. VIIIth Nord. vet. Congr. Helsingfors 1958, p. 455.

20. Thafvelin, B.: Medlemsbl. Sveriges Veterinärförb. 1960, 12, 205.

20 a. idem: Nature 1960, 188, 1169.

21. Tverdy, G., Froelich, A.-L. and Fierens, Br.: Acta gastro-enterol. Belg. 1949, 12, 221.

22. Wretlind, B., Orstadius, $K$. and Lindberg, P.: Zbl. Vet. Med. 1959, $6,963$.

\section{SUMMARY}

A vitamin-E-deficient basic diet, supplemented with cottonseed oil, was fed to pigs. Muscular dystrophy resulted with stripped oil which had not undergone any detectable oxidation, and with oils in which tocopherols had been more or less destroyed by heating. It is concluded that preformed lipid peroxides are not a pre-requisite for 
the production of muscular dystrophy. The amount of polyunsaturated fatty acids, notably linoleic acid, seems to be of paramount importance.

\section{ZUSAMMENFASSUNG \\ Erzeugung einer Muskeldystrophie bei Schweinen durch Fütterung mit Baumwollesamenöl.}

Die Schweine wurden unter Zusatz von Baumwollesamenöl an einer E-Vitaminarmen Diät gehalten. Die Muskeldystrophie wurde mit dem Baumwollesamenöl erzeugt, dessen E-Vitamingehalt man zum grössten Teil durch Molekylardestillation entfernte und bei dem keine messbare Oxydation nachzuweisen war, als auch mit den ölen bei denen das Vitamin E durch Erhitzen mehr oder weniger vernichtet wurde.

Die Verfasser ziehen den Schluss, dass die vorher gebildeten Fettsäureperoxyde im Futter für das Entstehen einer Muskeldystrophie nicht notwendig sind. Die Menge der ungesättigten Fettsäuren, besonders der Linolsäure, dürfte dagegen von entscheidender Bedeutung sein.

\section{SAMMANFATTNING}

Framkallande av muskeldystrofi hos svin genom utfodring med bomullsfröolja.

Vitamin-E-fattig diet, försatt med bomullsfröolja, utfodrades åt grisar. Muskeldystrofi erhölls med bomullsfröolja, vars E-vitamin till största delen avlägsnats genom molekylardestillation, samt med oljor, där E-vitaminet mer eller mindre förstörts genom upphettning.

Författarna drar slutsatsen, att preformerade fettsyreperoxider i fodret inte är nödvändiga för uppkomst av muskeldystrofi. Mängden polyomättade fettsyror, speciellt linolsyra torde vara av avgörande betydelse. 